\title{
Cicero Reading the Cyrenaics on the Anticipation of Future Harms
}

\author{
KATHARINE R. O'REILLY \\ University of Oxford
}

\begin{abstract}
A common reading of the Cyrenaics is they are a school of extreme hedonist presentists, recognising only the pleasure of the present moment, and advising against turning our attention to past or future pleasure or pain. Yet they have some strange advice which tells followers to anticipate future harms in order to lessen the unexpectedness of them when they occur. It's a puzzle, then, how they can consistently hold the attitude they do to our concern with our present selves, and yet endorse the practise of dwelling on possible future painful scenarios. To establish that this is a puzzle, though, we must first be convinced that the report is true. Cicero is our only clear source for the Cyrenaic advice, and scholars have noted reasons to be suspicious of the reliability of his report. I discuss these doubts, and why they ultimately fail to undermine Cicero's testimony as a source. Defending Cicero as a source for Cyrenaic thought removes a barrier to taking seriously an aspect of Cyrenaic psychology which could radically alter our understanding of their views.
\end{abstract}

A common reading of the Cyrenaics is that they are a school of extreme presentists when it comes to pleasure, recognising only the pleasure of the present moment, and advising against turning our attention away from present pleasure in favour of past or future pleasure. ${ }^{1}$ This is based on their epistemology, and their unique account of pleasure, wherein it is emphasised that all of our pathē are particular, unitary experiences, which are passively perceived, and where our only access to pleasure is access to the unitemporal (monochronos) pleasure of the moment, which is a motion that peters out in time. ${ }^{2}$ Part of the Cyrenaic doctrine on pleasure is that all pleasures are equal, each being as pleasant as the next. ${ }^{3}$ Thus, if the Cyrenaics denied that past or future pleasures are of any concern to them, they are in fact saying something stronger: that these are not pleasures at all. 
Yet we find in the ancient sources examples of the Cyrenaics discussing issues that would only be of interest to someone concerned with their future pathē: discussions of pleasure over a lifetime, the utility of friendship and prudence, and the purpose of wealth. ${ }^{4}$ Indeed, they connect happiness, which is comprised of particular pleasures, to pleasures of the past and future. ${ }^{5}$ Further, in their arguments about happiness, they say not that it is of no relevance, but that obtaining it necessitates taking some pain with the pleasure - a line moderate enough that Socrates would probably agree. ${ }^{6}$ And, rather problematically for those who consider the Cyrenaics extreme presentists, they also have some strange advice about future harms, as reported by Cicero:

The Cyrenaics consider that distress is not caused by every evil but by an unlooked for and unexpected evil. That, it is true, has no ordinary effect in heightening distress, for all sudden visitations seem more serious than others... This anticipation therefore of the future mitigates the approach of evils whose coming one has long foreseen. ${ }^{7}$

Cicero's testimony tells us that the Cyrenaics advised followers to anticipate future harms in order to lessen the unexpectedness of them when they occur. It's a puzzle, then, how they can consistently hold the attitude they do to our concern with our present, passively perceiving selves, and yet endorse the practise of dwelling on possible future distressing scenarios.

In order to establish that this is a puzzle, though, we must first be convinced that Cicero's report is true. As the evidence stands, Cicero is our only clear source for the Cyrenaic advice concerning the anticipation of future harms. Further, scholars have noted reasons to be suspicious of the reliability of his report. This doubt over the veracity of Cicero's testimony is thus a barrier to taking seriously an aspect of Cyrenaic psychology which could radically alter our understanding of their views, especially about the passivity of perception, their alleged presentism, and the nature of the pathe . As such, it's important to establish that this advice is genuinely Cyrenaic, and not simply a confused or tendentious report by Cicero (or indeed a report of his own view). Here I'll discuss the reasons for that worry, and why they ultimately fail to undermine Cicero as a source for Cyrenaic thought. ${ }^{8}$ My analysis here will be limited to the extra-philosophical reasons to doubt Cicero's report, by which I mean the reasons which do not concern how well or badly this advice sits with other Cyrenaic claims. Though I will 
conclude with some comments about how these relate to the philosophical grounds for evaluating the report, and its relation to Cyrenaic doctrine, this requires a separate, detailed analysis of its own. My motivation for this more confined defence is to open the door for this latter kind of analysis, which makes use of this piece of evidence, and could in turn change the way we understand Cyrenaic psychology, and how seriously we take their moral psychology and their therapy.

\section{Doubts over Cicero's testimony}

I see three possible, extra-philosophical foundations for suspicion about Cicero's reading of the Cyrenaics. The first is that his report has more to do with his own views on the anticipation of harms, and he uses the Cyrenaics as representative of a much more confined point about unexpectedness. The second is that Cicero's reading is misleading, implying that the advice is Cyrenaic when in fact the source is another school, such as the Stoics. The third, and closely related worry, is that though he doesn't deliberately mislead his reader, Cicero himself is misled about the source of the advice, and he is therefore an untrustworthy source. Here I'll interrogate each of these possibilities in turn, and I will argue that none of them should persuade us that Cicero is anything but a scrupulous and reliable reader of the Cyrenaics, and that his evidence of their thought is valid.

There are some reasons why we might worry that Cicero's emphasis, or indeed his whole reading of the Cyrenaics, has more to do with Cicero than those hedonists themselves. For a start, the passage with which I motivated the puzzle in the first place shows the founder of the school to take an attitude of indifference to pathe of the past and future, such that the advice to spend time anticipating possible future distress looks obviously suspicious against the background of the other evidence:

He [Aristippus] also argued that pleasure exists only in the individual moment [monochronos]; and like profligates generally, he believed that neither the memory of past pleasures nor the expectation of those to come was of any significance to him. 
Instead, he was of the opinion that the Good exists exclusively in the moment, and felt that having enjoyed himself before or being likely to do so again meant nothing to him, since the former was over, while the latter had not yet occurred and was uncertain; this is what hedonists feel, when they maintain that it is the moment that gives one pleasure. ${ }^{9}$

And if this sets our suspicions off, the Ciceronian report itself furthers that concern. Margaret Graver notes the suspicion with which this advice has been received by scholars:

... there has been some tendency in the literature to de-emphasize Cicero's report on Cyrenaic pre-rehearsal, or even dismiss it altogether. Mannebach excludes it from his collection of source texts, claiming that it is "ab Aristippi sententia aliena"; Giannantoni accepts it, but accords it only minimal comment. ${ }^{10}$ André Laks accepts Cicero's testimony and even finds it suggestive, but also describes it as "isolée et difficile."11 Reasons for this hesitation are not far to seek. Most accounts of Cyrenaic ethics understand a central text in Diogenes Laertius to say that for these hedonists, the proper goal of human existence is simply the pleasure of the present moment, while the long view which considers one's life of pleasure as a whole is of little concern. This reading is usually combined with passages in later sources which attribute to Aristippus the view that one should live exclusively for the present. An ethics whose sole effort is to maximize the pleasure of the present moment can hardly support a recommendation of the kind Cicero describes; consequently, Cicero's account must be regarded with suspicion. ${ }^{12}$

Graver herself shows initial suspicion, at first conceding that 'Cicero is admittedly not a reliable authority when it comes to the interpretation of hedonist views. His own philosophical preferences lie elsewhere, and his rhetorical bent often serves the ends of subtle misrepresentation.' ${ }^{13}$ But she offsets this initial scepticism with evidence to establish that the pre-rehearsal technique pre-dates even the earliest Cyrenaics, and then with a defence of Cicero as a reporter of early hedonist doctrine. ${ }^{14}$ Here is the former:

... what is the relation of this technique to the Cyrenaic school? Judging from the Euripides quotation, the technique itself must be quite old, going back to fifth-century Athens. It cannot then have been invented by Cyrenaic philosophers fifty to a hundred years later - and Cicero, who is normally attentive to chronology, must realize this. ${ }^{15}$ Yet he says a little further on that daily pre-rehearsal is their technique, that when he endorses it, he is accepting it "from the Cyrenaics" (3.31). The phrase does not quite commit him to a Cyrenaic origin for pre-rehearsal, but it does indicate that he believes that technique to have been associated with those philosophers in some particular way. And Cicero is most unlikely to have made such an assertion without some textual 
authority. We can safely conclude that he has seen pre-rehearsal mentioned in his source as the principal Cyrenaic method for dealing with grief. ${ }^{16}$

Richard Sorabji also points out the anticipation technique's Presocratic roots, with the practise going back to Anaxagoras, and also possibly found in Antiphon, the Pythagoreans, and Euripides, who was taught by Anaxagoras (according to Cicero). ${ }^{17}$ Graver goes on to defend Cicero as a source for Cyrenaic views:

... where he merely reports the claims of earlier philosophers, his evidence has to be taken very seriously: his sources are usually excellent, and he writes in the awareness of a readership who themselves have access to Greek works and will not tolerate fabrication. The passage in question here is rather spotty and disjointed in character, a bare report of claims rather than a coherent description of philosophical views. Cicero is undoubtedly summarizing some older work which had a particular interest in hedonist approaches. Indeed it is possible that he draws his information for both the Epicurean and Cyrenaic assertions from a work by Epicurus himself, perhaps the Peri Telous, which he quotes in extenso at 3.41-42. Alternatively, he may be relying on an earlier doxographical account. Even then, his information is of great value, for it may either confirm or modify the understanding of, especially, Cyrenaic thought which we ourselves have gained from various later doxographical and encyclopedic sources. ${ }^{18}$

So while Graver provides convincing evidence for the reported advice picking up on a pre-existent thread, there is more work to be done to defend the advice as genuinely Cyrenaic, rather than representing Cicero's own counsel. In the next section, I take on this task.

II The relationship between Cicero's testimony and the Cyrenaic advice

One way of reading the Tusculan Disputations is that all that Cicero attributes to the Cyrenaics directly is that 'distress is not caused by every evil but by an unlooked for and unexpected evil', while the next sentences express his own view, marked by the quidem. ${ }^{19}$ Let's look at the passage in detail in order to interrogate this possibility:

The Cyrenaics consider that distress is not caused by every evil but by an unlooked for and unexpected evil. That, it is true, has no ordinary effect in heightening distress, for all sudden visitations seem more serious than others. Hence it is that these lines are rightly 
praised: <Here follows a 3-line fragment from Ennius' Telamo $>$. This anticipation therefore of the future mitigates the approach of evils whose coming one has long foreseen. $<$ Here follows an introduction to and then citation from a lost tragedy of Euripides, translated into Latin $>{ }^{20}$

Take the expression '[h]ence it is that these lines are rightly praised'. Rightly praised by whom? Surely not the Cyrenaics, for they had no knowledge of Ennius. Nor can we take the Euripidean quotation to reflect their practise, since he was pre-Aristippan. One might think that they can only be rightly praised by Cicero himself, in an attempt to strengthen his anti-Epicurean, proCyrenaic stance. The sentence preceding that, '[t]hat, it is true, has no ordinary effect in heightening distress, for all sudden visitations seem more serious than others', could also express Cicero's own statement, since it differs from his reports of the Cyrenaics: according to them, an evil does not cause suffering if it is not unexpected (I'll call this the 'radical stance'). However, according to Cicero, an evil does not cause as much suffering if it is not unexpected (I'll call this the weaker stance). These would be only apparently related, on this reading, since the limited distress that arises from an anticipated evil for Cicero is incompatible with the distress-free state the Cyrenaic theory insists upon.

I think there are satisfactory responses to these worries about the relationship between Cicero's views and the advice he attributes to the Cyrenaics. In the first place, Cicero's endorsement of Ennius' and Euripides' expressions of the same idea he finds in the Cyrenaics is not evidence against the Cyrenaic origin of that idea. If Cicero thinks the Cyrenaics are right, about which he is explicit, that is enough of a connection, even if he embellishes the report with these references. In the second place, the distinction between Cicero's weaker or less radical stance, and what is possibly the more radical Cyrenaic stance, would in fact be grist to my mill. If the distinction is present, it indicates some distance between Cicero's view and the Cyrenaic view he is reporting, such that the independent existence of the two is reinforced.

The claim we find here is itself is a very striking one. Are we to understand Cicero's report to mean that the Cyrenaics believe distress to arise only where an event is unexpected (the radical stance), or that distress is just especially associated with unexpected ills? This 
problem of interpretation goes someway beyond my concern with the extra-philosophical reasons to doubt Cicero's testimony, but it is relevant to distinguishing the different parts of Cicero's report, and to disentangling his view from the one he attributes to the Cyrenaics. It's interesting to note that when this idea comes up again, at Tusc. Disp. III.xxi.59, Cicero connects unexpectedness claims with Chrysippus. We can wonder, then, whether Cicero is importing Stoic thought, with the strong reading wherein there are no pains that are not shock-related. Or indeed, whether the stronger reading could be a piece of Ciceronian satire.

A later passage which reinforces the connection between the Cyrenaics and this advice, though not deciding the issue of whether to take the more radical reading, appears at Tusc. Disp. III.xxi.51:

There remains the Cyrenaic view; they hold that distress arises where an event has happened unexpectedly. ${ }^{21}$

Here Cicero's choice of aegritudinem, which he also uses in the III.xiii.28-29 report, is interesting. In general this term tends to be used to refer to illness or sickness, though it can mean grief or sorrow. I've favoured the more neutral term 'distress', alongside 'harms' or 'evils' for malorem (in III.xiii.28), and 'event' for evenerit, so as not to prematurely decide the issues. Cicero's more common translation of pain (lupē), on the other hand, is dolorem.

If aegritudinem as the result of an unexpected harm or event does not refer to pain or suffering in general, but to some more particular type of distress, this could be significant for understanding what view exactly Cicero is attributing to the Cyrenaics. For instance, even the 'radical' reading I have outlined could be consistent with the claim that while the physical pain of a future harm is bad for the agent who suffers it, there is some aspect of the harm, some type of distress, which is caused by unexpected harms in particular, and can be avoided through an anticipatory practice. This would mean not that the Cyrenaics hold the view that an evil does not cause any pain if it is not expected, but that an evil does not cause a particular kind of distress if it is not unexpected. In particular, recalling that the Cyrenaics privilege physical pleasure and pain over mental pleasure and pain, ${ }^{22}$ the category of mental distress strikes me as particularly 
promising for an aspect of harm which the Cyrenaics could consider to be potentially avoidable. ${ }^{23}$

This last point is speculative, but it helps us resist the move to thinking that the anticipation advice is just Cicero's own view: if the Cyrenaic idea is that only unexpected evil causes this kind of suffering, this is just the kind of radical view Cicero would find appropriate for these radical hedonists. That could be so even if the full Cyrenaic view is more nuanced, in the way I have speculated about. So while it's not entirely clear that any version of the radical form is the Cyrenaic view (since more philosophical work would have to be done to establish as much), if it is, it does not damage Cicero as the reporter of their view, but rather clarifies the possible difference between their view and his.

If this more radical view is the right one to attribute to the Cyrenaics, more needs to be done to reveal the details of it. We should ask what would make them think that only unexpected evil causes distress (even if it is a particular type of distress), and what one could do about anticipating harms, if they did think this was so. If they held this view and had nothing therapeutic to say, this would be very odd. It would make much more sense if this extreme view was part of the motivation for a recommended technique or therapy, such as pro-active anticipation. While it is not within the scope of this paper to pursue these questions, establishing that this is their view, or at least removing a barrier to that possibility, would yield important new avenues of enquiry for research on the Cyrenaics.

\section{Cicero as a reporter of Cyrenaic advice}

The second time Cicero invokes the Cyrenaics could also generate a worry, along the same lines as the one described in the previous section. At Tusc. Disp. III.xv.31-32, Cicero again cites the Cyrenaics on anticipating future evil events: 
... in confronting the changes and chances of life I accept indeed from the Cyrenaics such weapons as they provide to enable me, with the help of long previous consideration, to break the coming of life's assaults, and at the same time I judge the evil we speak of to lie in belief and not in nature; for if it were downright reality, why should it be rendered lighter by anticipation? But a more accurate statement upon this same subject is possible, if we first consider the opinion of Epicurus, who supposes that all men must necessarily feel distress, if they think themselves encompassed by evils, whether previously foreseen and anticipated, or long established. For according to him evils are not lessened by duration nor lightened by previous consideration, and besides, he thinks it folly to dwell upon an evil which has still to come or maybe will not come at all...24

The phrase 'at the same time' (simulque) could indicate that the judgement that the evil lies in belief is different from these weapons (haec arma) which Cicero wishes to accept from the Cyrenaics. On that reading, he does not assert that premeditation is a weapon he wants to borrow from them. The weapon that he borrows is just what he had attributed to them earlier, namely their view that distress is not the natural effect of the presence of evils.

However, the phrases 'I judge' (iudico) and 'at the same time' (simulque) would be odd inclusions in reference to a phrase he had made up. In fact, the use of simulque could instead indicate just the opposite: heightening the contrast between Cicero's own point, and what he takes from the Cyrenaics. These distancing phrases seem to track the material of others, and call attention to the distinction, in a way which would be altogether appropriate for a known sceptic like Cicero, eager to separate the presentation of the material of others from what he believes or endorses.

The suspicious reader might be concerned that instead of indicating that the Cyrenaics urge premeditation, all these passages show is that Cicero himself promotes this practise, to which he explicitly commits himself, and show him exploiting a comment by the Cyrenaics in order to attack an Epicurean view which, if true, would make premeditation useless and irrational..$^{25}$ 
But we aren't compelled to read the passages in that way. I have shown that the evidence from the text instead indicates that Cicero at least takes himself to be reporting Cyrenaic advice, and his endorsement of the technique is an endorsement of what he understands to be their technique. The more detailed contrast with the Epicureans makes the Cyrenaic position firm by contrast, and it's not clear what the Cyrenaic weapons (arma) would be other than some technique which they endorse. Cicero's careful use of distancing language serves to heighten the otherwise subtle contrast between his view and that of the Cyrenaics. So Cicero's view looks to be at least not deliberately misleading.

Cicero's contention in these sections is to engage with and contrast the Epicurean stance that distress can be natural, and not always caused by false ideas. It could be that he exploits the Cyrenaic view in order to criticise the Epicureans, though he is elsewhere extremely critical of Cyrenaic views. Indeed, the use of the Cyrenaics versus Epicureans framework is rare in Cicero, so it's justified that we should be especially attentive to his motivation for this set-up. The Cyrenaic view could be here to undermine the Epicurean view, in that it shows that if it is only unexpected harms that bring distress (at least of a certain kind), the harms themselves don't have distress as their natural consequence, which is the Epicurean view.

But I don't see why we have to read Cicero this way, either. The context of Tusc. Disp. is a dialectical engagement with both hedonist schools, in which Cicero self-consciously takes views from whatever sources he can find, as the basis for interrogation, and the eventual recommendations of his therapeutic work. He accepts the idea that therapy is about whatever works, regardless of the source. Given the self-consciously dialectical context of these two passages, Cicero lacks motivation for distorting what he takes to be the Cyrenaic ideas. Even in his most polemical moods, he is scrupulous regarding the representation of ideas he intends to attack. The fact that it sounds a bit Stoic isn't itself a problem. After all, all the ancient schools were trying to solve the same broad problems, and to address the same philosophical issues. Cicero's project was to line up friends and enemies in order to yield the best therapy, and these passages are right in keeping with that method. 
There is a second type of worry, which is that Cicero may be reporting what he takes to be an accurate account of Cyrenaic doctrine, but which may in fact be Stoicised. Cicero does claim to quote verbatim, but Graver is in danger of exaggerating his claim when she says that he is 'undoubtedly summarizing some older work' ${ }^{26}$ Anti-Epicurean sources are just as likely to be his source for quotations from the Peri Telous, including the Stoic version of the Carneadea divisio, which made much of Cyrenaic views, and which Cicero's source could just as easily have depended on. ${ }^{27}$ The Stoics could have motivation for finding this same advice amongst other schools - if, for example, they want to make a claim about even the ultra-hedonists practising this, without the idea that they were necessarily being hostile in doing so. The worry isn't that they would have fabricated it, but just that they would have a desire to see it elsewhere, and that in turn Cicero's belief that it was genuinely part of their system isn't good enough evidence it itself.

It is the case that the technique of anticipating possible future harms as part of a psychological defence technique is most closely associated with Stoicism. Furthermore, given that representatives of the Cyrenaic sects may have disappeared long before Cicero's time, it is very possible that either Cicero's source could have distorted the Cyrenaic doctrine, or that Cicero himself read into the texts something that was not intended by the Cyrenaics themselves.

However, the fact that Cicero himself is our only source attesting to this advice does not in itself constitute sufficient reason for questioning the Cyrenaic origin of the doctrine. There are precedents for accepting ancient doctrine based on single sources, provided those sources are generally reliable (as I have established Cicero to be), and barring either historical or philosophical reasons to be sceptical of the claims. ${ }^{28}$ Historically, we have said that the argument can go either way: we can understand Cicero to be a scrupulous source, but still worry that either his source misleads him, or that he himself misunderstands what he reads. So the question ought to be decided primarily on philosophical grounds. Doing so requires us to 
decide whether the anticipation technique is incompatible with the other parts of accepted Cyrenaic thought. I hope to have shown, by addressing scholarly worries over the veracity of Cicero's testimony, that pursuing that question, and taking the puzzle it generates seriously, is both possible and worthwhile as a new avenue of interest in Cyrenaic moral psychology. ${ }^{29}$

\section{BIBLIOGRAPHY}

Annas, J. (1993). The Morality of Happiness. New York: Oxford University Press.

Döring, K. (1998). Der Sokratesschuler Aristipp und die Kyrenaiker. Stuttgart: Akademie der wissenschaften und der Literatur Mainz.

Gosling, J.C.B. and C.C.W. Taylor (1982). The Greeks on Pleasure. Oxford: Oxford University Press.

Irwin, T. (1991). 'Aristippus against happiness' in Monist: 74.1, 55-82.

Giannantoni, G., ed. (1990). Socratis et Socraticorum reliquiae. 4 vols. Naples: Bibliopolis.

Graver, M. (2001). 'Managing Mental Pain: Epicurus vs. Aristippus on the Pre-Rehearsal of Future Ills' in Proceedings of the Boston Area Colloquium in Ancient Philosophy 17, 155-177.

Laks, A. (1993). 'Annicéris et les plaisirs psychiques: quelques préalables doxographiques' in J. Brunschwig and M. Nussbaum., eds.(1993). Passions and perceptions: studies in Hellenistic philosophy of mind. Cambridge: Cambridge University Press, 18-50.

Long, A.A (1999). 'Aristippus and Cyrenaic Hedonism' in Algra et al. (1999), 632-38.

Mannebach, E. (1961). Aristippi et Cyrenaicorum fragmenta. Leiden: Brill.

Mitsis, P. (1988). Epicurus' Ethical Theory: The Pleasures of Invulnerability. Ithaca and London: Cornell University Press.

O’Keefe, T. (2002). ‘The Cyrenaics on Pleasure, Happiness, and Future Concern' in Phronesis 47, 395-416.

Sedley, D. (2017). 'Epicurean versus Cyrenaic Happiness' in Selfhood and the Soul: Essays on Ancient Thought and Literature in Honour of Christopher Gill, ed. R. Seaford, J. Wilkins, and M. Wright. Oxford: Oxford University Press.

Sorabji, R. (2002). Emotion and Peace of Mind: From Stoic Agitation to Christian Temptation. Oxford: Oxford University Press. 
Tsouna-McKirahan, V. (2002). 'Is there an exception to Greek eudaimonism?' in M. Canto and P. Pellegrin (eds.), Le style de la pensée: Mélanges J. Brunschwig. Paris: Belles Lettres, 464-89.

-- (1998). The Epistemology of the Cyrenaic school. Cambridge: Cambridge University Press.

Warren, J. (2014). “The Cyrenaics” in The Routledge Companion to Ancient Philosophy, eds. J. Warren and F. C. C. Sheffield. London, 409-22.

-- (2001). "Epicurus and the pleasures of the future" in Oxford Studies in Ancient Philosophy 21.

\footnotetext{
${ }^{1}$ Graver (2001) 162 agrees that this has become the standard reading, citing, for example, Gosling and Taylor (1982) 41-42; Döring (1988) 40-42; Mitsis (1988) 51-57; Irwin (1991); Annas (1993) 230-32; Tsouna-McKirahan (1998) 14-18; and Long (1999). Recent scholarship has begun to favour a more moderate reading. Defenders of this include Warren (2001) 167-8; Graver (2001) 162-3; Tsouna-McKirahan (2002) 464-89; O’Keefe (2002); Warren (2014) 191-3; and Sedley (2017) 5-6.

${ }^{2}$ For example Athenaeus, Deipnosophistai XII.544a, which is reproduced below (\$1). See also Aelian, Various History (frr. 207-08 Mannebach) 14.6, and Sextus Empiricus, Against the Professors I.117, I.226, for similar accounts. TsounaMcKirahan (1998) 17-18 argues that this should be understood as unitary and singular, with no prospective or retrospective value.

${ }^{3}$ Diogenes Laertius, Lives of Eminent Philosophers, II.87 (hereafter 'Lives'). All translations are from volume II, Books 610, trans. R.D. Hicks. Harvard: Harvard University Press (Loeb Classical Library) No. 185, (1925).

${ }^{4}$ Ibid., II.87-92.

${ }^{5}$ For example: 'However, the bodily pleasure which is the end, according to Panaetius in his work On the Sects, [is] not the settled pleasure following the removal of pains, or the sort of freedom from discomfort which Epicurus accepts and maintains to be the end. They also hold that there is a difference between "end" and "happiness". Our end is particular pleasure, whereas happiness is the sum total of all particular pleasures, in which are included both past and future pleasures' (Lives II.87).

${ }^{6}$ Ibid., II.88, 90.

${ }^{7}$ Cicero, Tusculan Disputations III.xiii.28-29, trans. J. E. King (1971). Here is the Latin, from the same edition: Cyrenaici non omni malo aegritudinem effici censent, sed insperato et necopinato malo. Est id quidem non mediocre ad aegritudinem augendam; videntur enim omnia repentina graviora... [29] haec igitur praemeditatio futurorum malorum lenit eorum adventum, quae venientia longe ante videris.

${ }^{8}$ In preparing $\$ \S 1$ and 3 I am especially indebted to helpful exchanges with Professors Margaret Graver, D. S.

Hutchinson, David Sedley and Voula Tsouna, in private correspondence which should be understood to express only provisional thoughts and challenges, given that context.

${ }^{9}$ Athenaeus, Deipnosophistai Book XII, 544a-b, trans. S. Douglas Olson (2010). See also Aelian, Various History (frr. 20708 Mannebach) 14.6 for a similar account.

${ }^{10}$ Here Graver notes (her n. 15): Mannebach 1961, 96; cf. Giannantoni 1990, vol. 4, 183.

${ }^{11}$ Here Graver notes (her n. 16): Laks 1993, 33.

${ }^{12}$ Graver (2001) 162.

${ }^{13}$ Ibid., 157.

${ }^{14}$ See $\$ 2$ for a version of the passage which indicates where the Ennius and Euripides references appear.

${ }^{15}$ Here Graver notes (her n. 14): 'Aristippus the Elder might have been a younger contemporary of Euripides. But it would be fanciful to credit him with the invention of the method, which had a much wider currency than any view associated with him... Cicero's own enthusiasm for the technique confuses the matter for source criticism: the quotation from Terence is certainly his own embellishment (perhaps substituted for a Menander quotation in his source), and some of the discussion as well.'

${ }^{16}$ Graver (2001) 161-2.
} 
${ }^{17}$ Sorabji (2002) 235, citing Antiphon fragments 3 and 5 (DK), which speaks of the unprepared mind (aparaskeuōi gnōmēsi) and the sufferings that are not sufferings (pathe apathē). For the Pythagoreans he cites Iamblichus On the Pythagorean Way of Life 196, and for Euripides he cites (?)Plutarch, who quotes him, in Consolation to Apollonius 112D. Cicero's note is cited from Tusc. Disp. 3.29-30.

${ }^{18}$ Graver (2001) 157-8.

${ }^{19}$ Irwin (1991) 81, n. 29, notes as much, in reference to Tusc. Disp. iii 28-29: 'The last two sentences are Cicero's expressions of agreement with the Cyrenaics, rather than an explicit report of their view.'

${ }^{20}$ Cicero, Tusc. Disp. III.xiii.28-29, trans. J. E. King (1971). Here is the Latin, from the same edition:

Cyrenaici non omni malo aegritudinem effici censent, sed insperato et necopinato malo. Est id quidem non mediocre ad aegritudinem augendam; videntur enim omnia repentina graviora. Ex hoc et illa iure laudantur : $<3$ lines from Ennius>. [29] haec igitur praemeditatio futurorum malorum lenit eorum adventum, quae venientia longe ante videris. <Introduction to and citation of Euripides>.

${ }^{21}$ Trans. J. E. King. Here is the Latin, from the same edition: Cyrenaicorum restat sententia, qui tum aegritudinem censent exsistere, si necopinato quid evenerit.

${ }^{22}$ Lives II.90.

${ }^{23} \mathrm{I}$ am particularly indebted to Tim O'Keefe for pushing me on this point, and for offering helpful suggestions.

${ }^{24}$ Cicero, Tusc. Disp. III.xv. 31-32, trans. J. E. King. Here is the Latin, from the same edition: Qua re accipio equidem a Cyrenaicis haec arma contra casus et eventus, quibus eorum advenientes impetus diuturna praemeditatione frangantur, simulque iudico malum illud opinionis esse, non naturae ; si enim in re esset, cur fierent provisa leviora? Sed est iisdem de rebus quod dici possit subtilius, si prius Epicuri sententiam viderimus, qui censet necesse esse omnes in aegritudine esse, qui se in malis esse arbitrentur, sive illa ante provisa et exspectata sint sive inveteraverint. Nam neque vetustate minui mala nec fieri praemeditata leviora, stultamque etiam esse meditationem futuri mali aut fortasse ne futuri quidem.

${ }^{25}$ This would be an example of a rhetorical technique of showing that my enemy's enemy is my friend, which in this case would cause confusion about the extent of the alliance between Cicero and his enemy (Epicurus)'s enemy (the Cyrenaics).

${ }^{26}$ Graver (2001) 157-8. See note 18, above.

${ }^{27} \mathrm{I}$ am indebted to David Sedley for pointing out this objection in personal correspondence. I am also indebted to Margaret Graver, who clarified some further reasons which might incline us to think first of the Peri Telous as the source for this reference. The first is that we have one good data point in the lengthy quotation from that work right nearby, a passage which, like this passage, does not appear in De Finibus. The second is that the pieces of information Cicero has concerning the Cyrenaics align well with the corresponding points about Epicurus, in a manner that seems to accord well with him having acquired them from a longer Epicurean discussion which criticized the rival school point-for-point, or otherwise from some doxographical source that would have summarised some such discussion. Graver continues to doubt that if Cicero used a textual source for the information he gives about the Cyrenaics in De Finibus, that source was the Carneadea divisio, given that we have no reason to think that the Carneadea divisio contained this type of information about that school, or any other.

${ }^{28}$ Voula Tsouna helpfully pointed out (in private correspondence), regarding this point, that no one, for example, questions Hegesias' intellectualism on the grounds that it is attested by only one source.

${ }^{29}$ For discussions of this paper, in various stages of its development, my thanks to Peter Adamson, Raphael Woolf, Joachim Aufderheide, Richard Sorabji, Voula Tsouna, George Boys-Stones, D. S. Hutchinson, David Sedley, Margaret Graver, Tim O'Keefe, Karen Margrethe Nielsen, Marta Jimenez, Jeremy Bell, Ana Laura Edelhoff, and audience members at the Ancient Philosophy Society, Emory University, Atlanta, and the Ancient Philosophy Workshop for Female Graduate Students and Early Career Researchers, Somerville College, Oxford. This research was supported by the Arts \& Humanities Research Council, and the Analysis Trust. This paper is dedicated to Wendy O'Reilly. 